Indo. J. Chem. Res., 2018, 5(2), 96-100

\title{
ANALISIS SERBUK BIJI KELOR (Moringa Oleifera, Lamk) DALAM MENURUNKAN KADAR COD DAN BOD PADA AIR LIMBAH JASA LAUNDRY
}

\section{Analysis of Kelor Seed Powder (Moringa Oleifera, Lamk) in Reducing COD and BOD Levels on Wastewater Services Laundry}

\author{
Waode Rustiah $^{1 *}$, Yuli Andriani ${ }^{2}$ \\ ${ }^{1}$ Health Analyst Study Program, Health Analyst Academy Muhammadiyah Makassar, \\ Jalan Dr. Ratulangi No. 101 Makassar - Indonesia \\ ${ }^{2}$ Department of Chemistry, Faculty of Science and Technology, Islamic State Alauddin University \\ Makassar, Jalan H.M. Yasin Limpo. N0.36, Campus II Samata Gowa - Indonesia \\ *Corresponding author, e-mail: tia_devina@yahoo.com
}

Received: Dec. 2017 Published: Jan. 2018

\begin{abstract}
Water pollution at this time is very apprehensive especially many laundry businesses are located around the home residents. Waste laundry waste water is a derivative of organic substances. The content of organic substances in waste water laundry services has resulted in high levels of COD and BOD of water, which can cause pollution to the environment and become toxic to life in the water. Therefore it is necessary to do a solution to overcome the contamination, such as by using coagulant seed of Moringa Oleifera, Lamk. The purpose of this study is to determine the effectiveness of Moringa Oleifera, Lamk seed coagulant in lowering the levels of COD and BOD on laundry waste laundry services. Based on the results of the study, it can be concluded that the excellent COD decrease obtained at the weight of 0.7 grams of $250 \mathrm{mg} / \mathrm{L}$ with an efficiency of $35 \%$, while the BOD measurement, the best weight in lowering BOD levels is 3.6 grams amounted to 11.616 $\mathrm{mg} / \mathrm{L}$ with a decrease presentation worth $57.66 \%$.
\end{abstract}

Keywords: Water pollution, laundry, COD, BOD, Moringa Oleifera Lamk.

\section{PENDAHULUAN}

Masalah pencemaran air sudah sangat memprihatinkan bagi masyarakat yang diakibatkan dari limbah-limbah buangan baik rumah tangga maupun industri. Banyaknya usaha jasa cuci pakaian atau laundry yang berada di sekitar rumah warga, misalnya di kompleks perumahan Bumi Tamalanrea Permai (BTP), dimana 1 blok memiliki 3 usaha jasa laundry, sehingga air limbahnya dapat menimbulkan permasalahan serius.

Air limbah jasa laundry mengandung detergen yang mana bahan-bahan komposisinya dapat menyebabkan toksik bagi kehidupan dalam air. Selain itu, detergen merupakan suatu derivatik zat organik, dimana jenis bahan organik pada limbah jasa laundry ini dibedakan menjadi minyak (oil) dan lemak (grease). Kebutuhan oksigen biokimia Biochemical Oxygen Demand (BOD) adalah jumlah oksigen yang dibutuhkan oleh mikroorganisme untuk penghancuran senyawa organik maupun anorganik dalam waktu tertentu, sedangkan kebutuhan oksigen kimia (COD) adalah banyaknya oksigen yang dibutuhkan untuk mengoksidasi bahan-bahan organik secara kimia. Air limbah jasa laundry juga memiliki kadar BOD dan COD yang cukup tinggi yaitu 195 ppm, padahal batas baku suatu air adalah hanya $30 \mathrm{ppm}$. Untuk menurunkan Kadar BOD dan COD yang diakibatkan dari meningkatnya senyawa organik pada limbah cair, maka penanggulangannya sangat cocok menggunakan proses koagulasi (Rukaesih, 2004; Trestianingrum, 2013).

Koagulasi merupakan proses yang memanfaatkan ion-ion, dimana mempunyai muatan berlawanan dengan muatan koloid yang terdapat dalam limbah cair, sehingga meniadakan kestabilan ion. Prinsip dasar proses koagulasi adalah terjadinya gaya tarik menarik antara ion-ion negatif disuatu pihak dengan ionion positif di pihak lain. Yang bertindak sebagai ion negatif adalah partikel-partikel yang terdiri dari zat-zat organik (partikel koloid), mikoorganisme dan bakteri (Suwahyono, 2008; Bangun, dkk. 2014). Salah satu koagulan alami yang dapat digunakan untuk menjernihkan air yaitu serbuk biji kelor. 


\section{Waode Rustiah dkk. / Indo. J. Chem. Res., 2018, 5(2), 96-100}

Biji kelor merupakan salah satu tanaman yang dapat dipergunakan sebagai salah satu koagulan alami alternatif yang tersedia secara lokal. Bangun, dkk., 2014 dalam penelitiannya menemukan bahwa biji kelor adalah bahan alami yang dapat membersihkan limbah cair, relatif sama efektifnya bila dilakukan dengan cara pembersihan menggunakan bahan kimia. Biji kelor telah dilaporkan efektif sebagai koagulan untuk menurunkan kekeruhan pada limbah cair dan biji kelor juga tidak mengandung senyawa toksik sehingga aman bagi kesehatan dan ramah lingkungan.

Zat aktif yang berperan sebagai koagulan yang terdapat pada biji kelor yaitu 4-alfa-4rhamnosyloxy-benzil-isothiocyanate yang terkandung dalam biji kelor. Zat aktif ini mampu mengadsorpsi partikel-partikel air limbah. Dengan pengubahan bentuk menjadi yang lebih kecil, maka zat aktif dari biji kelor tersebut akan semakin banyak, karena luas permukaan biji kelor semakin besar (Bangun, 2013).

Berdasarkan latar belakang di atas maka pada penelitian ini telah dilakukan analisis serbuk biji kelor (Moringa Oleifera, Lamk) dalam menurunkan kadar COD dan BOD pada air limbah jasa Laundry.

\section{METODOLOGI}

\section{Bahan}

Bahan-bahan yang digunakan antara lain biji kelor, air limbah, $\mathrm{K}_{2} \mathrm{Cr}_{2} \mathrm{O}_{7}, \mathrm{Ag}_{2} \mathrm{SO}_{4} / \mathrm{H}_{2} \mathrm{SO}_{4}$, $\mathrm{HgSO}_{4}$, indikator ferroin, $\mathrm{H}_{2} \mathrm{SO}_{4}, \mathrm{MnSO}_{4}$.

\section{Alat}

Adapun alat-alat yang digunakan antara lain pisau, oven, ayakan 40 mesh, peralatan gelas, tabung hach, pipet tetes, pipet volum, jerigen, blender, botol Winkler.

\section{Prosedur kerja \\ Preparasi Serbuk Biji Kelor}

Biji kelor diambil di daerah perkebunan Desa Pannara, Kecamatan Binamu, Kabupaten Jeneponto, Provinsi Sulawesi Selatan. Diambil buah kelor yang sudah tua dan kering. Buah kelor dibuka dan diambil biji kelor yang sudah tua dan berwarna cokelat, kemudian dihaluskan menggunakan blender dan dikeringkan pada suhu ruang selama 24 jam, selanjutnya dimasukkan ke dalam oven selama 1 jam pada suhu $110^{\circ} \mathrm{C}$ dan diayak menggunakan ayakan ukuran 40 mesh, hingga diperoleh serbuk biji kelor berwarna putih dan halus.

\section{Persiapan Sampel Biji Kelor}

Serbuk biji kelor ditimbang masing-masing sebanyak 0,$3 ; 0,4 ; 0,5 ; 0,6$ dan 0,7 gram untuk pengukuran COD dan dimasukkan ke dalam gelas kimia $250 \mathrm{~mL}$ yang berisi sampel cair limbah jasa cuci pakaian. Sedangkan untuk pengukuran $\mathrm{BOD}$, ditimbang serbuk biji kelor masing-masing sebanyak 1,$8 ; 2,4 ; 3,0 ; 3,6$ dan 4,2 gram dan memasukkan ke dalam gelas kimia $300 \mathrm{~mL}$ yang berisi sampel cair limbah jasa cuci pakaian.

\section{Persiapan Sampel Cair Limbah Jasa Laundry}

Air limbah jasa laundry diambil di salah satu usaha cuci pakaian di Kompleks BTP, Makassar. Usaha cuci pakaian ini mulai berjalan sejak tahun 2012 hingga sekarang dan limbah yang dihasilkan dibuang langsung ke dalam selokan yang kira-kira memiliki kedalaman dan luas sekitar 1 meter. Sampel air limbah diambil langsung dari pipa pembuangan menggunakan ember dan ditampung langsung pada jergen berwarna gelap.

\section{Penentuan COD dengan Metode Refluks Tertutup}

Larutan $\mathrm{K}_{2} \mathrm{Cr}_{2} \mathrm{O}_{7}$ 0,25 $\mathrm{N}$ dipipet sebanyak $1 \mathrm{~mL}$ dimasukkan ke dalam tabung hach, selanjutnya dipipet sebanyak $1 \mathrm{~mL}$ $\mathrm{Ag}_{2} \mathrm{SO}_{4} / \mathrm{H}_{2} \mathrm{SO}_{4} 1 \%$, dan ditambahkan 0,04 gram $\mathrm{HgSO}_{4}$. Setelah itu, ke dalam tabung hach dimasukkan masing-masing $2 \mathrm{~mL}$ blanko dan 2 $\mathrm{mL}$ sampel. Kemudian tabung hach ditutup rapat dan dihomogenkan. Meletakkan tabung hach yang berisi larutan pada reaktor COD, kemudian direfluks pada suhu $150^{\circ} \mathrm{C}$ selama 2 jam. Setelah itu, tabung didinginkan dan larutan dimasukkan ke dalam erlenmeyer, ditambahkan 2 tetes indikator ferroin dan dititrasi dengan larutan Ferro Ammonium Sulfat (FAS), hingga terjadi perubahan warna yang jelas dari hijau/biru menjadi cokelat kemerah-merahan. Selanjutnya menghitung kadar COD sebelum dan sesudah perlakuan baik. 


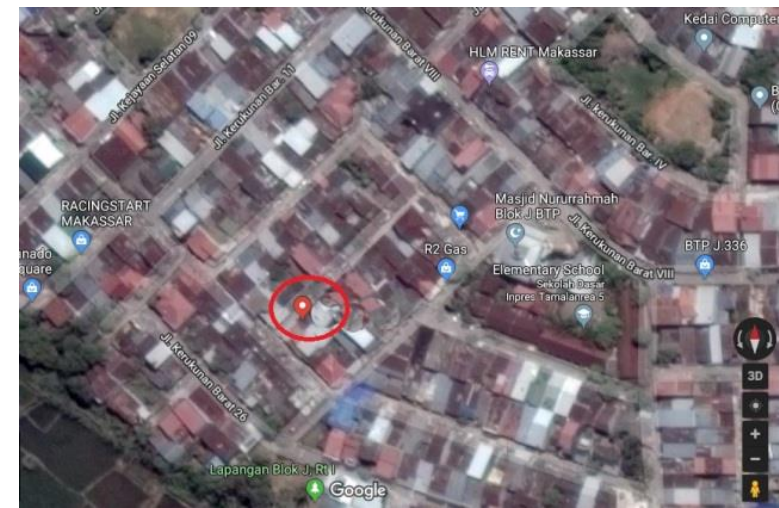

Gambar 1 Lokasi pengambilan sampel (508'26.3"S 119³0'22.1"E)

\section{Penentuan BOD dengan Metode Titrasi Winkler}

Uji kadar BOD dilakukan dengan cara pemeriksaan oksigen terlarut nol hari dari satu botol Winkler yang berisi sampel uji. Kemudian botol Winkler lain yang berisi sampel uji diinkubasi selama 5 hari pada suhu $20^{\circ} \mathrm{C}$. Selanjutnya masing-masing botol Winkler ditambahkan sebanyak $1 \mathrm{~mL}$ larutan $\mathrm{MnSO}_{4}$, dan $1 \mathrm{~mL}$ larutan alkali iodida azida, lalu ditutup rapat dan dihomogenkan. Gumpalan dibiarkan mengendap selama 5 menit. Selanjutnya ditambahkan $1 \mathrm{~mL} \mathrm{H}_{2} \mathrm{SO}_{4}$ pekat lalu ditutup dan dihomogenkan kembali. Setelah itu, dipipet sebanyak $50 \mathrm{~mL}$ dan dimasukkan ke dalam erlenmeyer $250 \mathrm{~mL}$, ke dalamnya ditambahkan 2 tetes indikator amilum dan dititrasi dengan natrium tiosulfat hingga berubah warna dari biru menjadi jernih. Selanjutnya menghitung kadar BOD sebelum dan sesudah perlakuan.

\section{HASIL DAN PEMBAHASAN}

Lokasi penelitian ini dilakukan pada salah satu jasa laundry yang berada di kompleks perumahan BTP yakni pada titik koordinat 508'26.3"S 119³0'22.1"E seperti pada Gambar 1. Pemilihaan lokasi ini dengan pertimbangan lokasi ini memiliki pelanggan cukup banyak, sehingga aktivitas pembuangan limbahnya cukup besar. Berdasarkan hasil penelitian yang dilakukan, diperoleh hasil penurunan kadar COD dan BOD menggunakan serbuk biji kelor dengan berbagai variasi waktu, dapat dilihat pada Tabel 1

Pada Tabel 1 dapat dilihat efektifitas serbuk biji kelor pada masing-masing variasi berat dalam menurunkan kadar COD limbah. Untuk berat koagulan terkecil yaitu 0,3 gram, presentasi penurunan bernilai $5 \%$. Pada berat 0,4 gram, presentase penurunan meningkat 5,95\%. Pada berat 0,5 gram, presentasi penurunan meningkat menjadi $20,00 \%$. Tingginya presentasi ini menunjukkan kerja koagulan yang sangat baik dengan semakin beratnya koagulan yang digunakan.

Tabel 1 Data kadar COD terhadap variasi berat serbuk biji kelor

\begin{tabular}{ccc}
\hline $\begin{array}{c}\text { Berat Serbuk } \\
\text { Biji Kelor } \\
\text { (gram) }\end{array}$ & $\begin{array}{c}\text { Kadar COD } \\
(\mathbf{m g} / \mathbf{L})\end{array}$ & $\begin{array}{c}\text { Efisiensi } \\
(\%)\end{array}$ \\
\hline 0 & 384,63 & 0 \\
0,3 & 365,39 & 5,00 \\
0,4 & 361,75 & 5,95 \\
0,5 & 307,70 & 20,00 \\
0,6 & 265,39 & 31,00 \\
0,7 & 250,00 & 35,00 \\
\hline
\end{tabular}

Tabel 2 Data Kadar BOD Terhadap Variasi Berat Serbuk Biji Kelor

\begin{tabular}{ccc}
\hline $\begin{array}{c}\text { Berat Serbuk } \\
\text { Biji Kelor } \\
(\text { gram })\end{array}$ & $\begin{array}{c}\text { Kadar BOD } \\
(\mathbf{m g} / \mathbf{L})\end{array}$ & $\begin{array}{c}\text { Efisiensi } \\
(\boldsymbol{\%})\end{array}$ \\
\hline 0 & 27,437 & 0 \\
1,8 & 23,348 & 14,90 \\
2,4 & 19,167 & 30,14 \\
3,0 & 19,360 & 29,43 \\
3,6 & 11,616 & 57,66 \\
4,2 & 23,232 & 15,32 \\
\hline
\end{tabular}

Pada Tabel 2 terlihat efektifitas serbuk biji kelor pada masing-masing variasi berat koagulan. Berat koagulan yang paling optimal menyerap terjadi pada berat 2,4 gram dengan presentasi penurunan senilai $30,14 \%$ sedangkan pada saat penambahan koagulan dengan berat 3 gram, kadar BOD kembali meningkat dengan presentasi penurunan yaitu $29,43 \%$. Hal ini terjadi karena dengan bertambahnya berat koagulan yang berlebih dalam limbah cair akan menyebabkan interaksi antara kogulan dan limbah cair yang menyebabkan terjadinya penggumpalan koagulan, mengakibatkan berkurangnya luas permukaan aktif dari koagulan, sehingga menghasilkan proses penyerapan tidak efektif (Yudo, 2010; Hidayat, 2009). 


\section{Waode Rustiah dkk. / Indo. J. Chem. Res., 2018, 5(2), 96-100}

Kandungan Zat aktif yang terdapat pada biji kelor yang bersifat sebagai koagulan yaitu 4alfa-4-rhamnosyloxy-benzil-isothiocyanate yang cenderung bermuatan positif, sehingga mampu mendestabilisasikan koloid yang bermuatan negatif. Berikut mekanisme koagulasi serbuk biji kelor dalam limbah cair jasa laundry (Khasanah, 2008; Trestianingrum dkk., 2013).

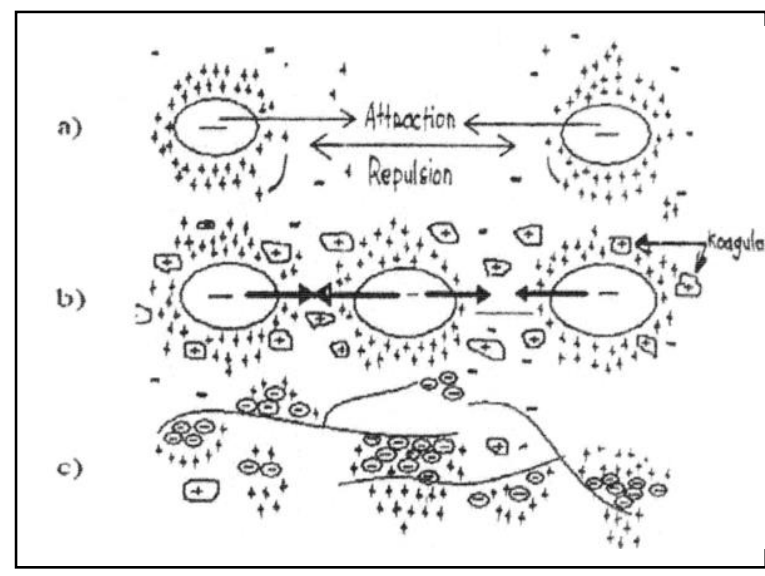

Gambar 2 Mekanisme koagulasi serbuk biji kelor pada limbah cair

Kebutuhan koagulan atau dosis koagulan pada proses koagulasi air keruh tergantung pada jenis air keruhnya. Air dengan tingkat kekeruhan tinggi membutuhkan dosis koagulan yang tepat sehingga proses pengendapan partikel koloid pada air keruh berlangsung dengan baik. Pada mekanisme diatas dapat dilihat pada Gambar 2a gaya yang ditunjukkan oleh partikel koloid pada kondisi stabil. Kemudian pada Gambar 2b terjadi destabilisasi partikel koloid oleh penambahan koagulan sehingga terjadi pembentukan flok-flok yang terikat membentuk benang panjang (Bangun, 2013).

Pada proses pengukuran COD ini menggunakan metode refluks tertutup, dimana prinsip pengukurannya adalah zat organik dioksidasi dengan campuran mendidih asam sulfat dan kalium dikromat yang diketahui normalitasnya dalam sebuah refluks selama 2 jam. Kelebihan kalium dikromat yang tidak direduksi, dititrasi dengan larutan ferro ammonium sulfat (FAS). Pengukuran COD juga menggunakan $\mathrm{HgSO}_{4}$ yang bertujuan untuk menghilangkan adanya gangguan dari ion klorida. Ion merkuri akan bergabung dengan dengan ion klorida membentuk merkuri klorida. Sehingga dengan adanya ion $\mathrm{Hg}^{2+}$ ini, konsentrasi dari ion klorida menjadi sangat kecil dan tidak mengganggu oksidasi senyawa organik (Manurung dkk., 2012; Wahyuni, 2011).

Pengukuran BOD pada penelitian ini menggunakan metode titrasi Winkler yang didasarkan pada oksigen dalam sampel yang mengoksidasi $\mathrm{MnSO}_{4}$ menjadi endapan $\mathrm{MnO}_{2}$ dimana dengan adanya penambahan $\mathrm{H}_{2} \mathrm{SO}_{4}$ dan $\mathrm{KI}$ akan dibebaskan iodine yang ekuivalen dengan jumlah oksigen terlarut. Besarnya nilai BOD dihitung dari selisih kadar okisigen sebelum dan sesudah inkubasi selama 5 hari. Pengukuran BOD dapat dipergunakan untuk menaksir beban pencemaran zat organik. Penentuan waktu inkubasi selama 5 hari dapat mengurangi kemungkinan adanya gangguan dari hasil oksidasi ammonia yang cukup tinggi yang dapat mengganggu dalam pengukuran (Noviani, 2012; Nasir, 2013).

\section{KESIMPULAN}

Berdasarkan hasil penelitian, maka dapat disimpulkan bahwa pada biji kelor penurunan COD yang sangat baik diperoleh pada berat 0,7 gram sebesar 307,70 mg/L, sedangkan untuk pengukuran BOD pada koagulan biji kelor berat yang paling baik dalam menurunkan kadar BOD adalah 2,4 gram sebesar 19,167 mg/L.

\section{DAFTAR PUSTAKA}

Bangun, A. R., Siti Aminah, Rudi Anas Hutahaean, M. Yusuf Ritonga, 2013, Pengaruh Kadar Air, Dosis Dan Lama Pengendapan Koagulan Serbuk Biji Kelor Sebagai Alternatif Pengolahan Limbah Cair Industri Tahu, Jurnal Teknik Kimia USU, 2(1), 1-5.

Hidayat, S., 2009, Protein Biji Kelor Sebagai Bahan Aktif Penjernihan Air. Biospesies, 2(2), 12-17.

Khasanah, H., 2008, Efektifitas Biji Kelor (Moringa Oleifera, LAMK) Sebagai Koagulan Fosfat Dalam Limbah Cair Rumah Sakit (Studi Kasus di RSU Dr. Saiful Anwar Malang), Skripsi, Jurusan Kimia, Fakultas Sains dan Teknologi, Universitas Islam Negeri (UIN) Malang.

Manurung, T., Dewi, Y. S., Lekatompessy, B. J., 2012, Efektifitas Biji Welor (Moringa oleifera) Pada Pengolahan Air Sumur 
Waode Rustiah dkk. / Indo. J. Chem. Res., 2018, 5(2), 96-100

Tercemar Limbah Domestik, Jurnal Ilmiah Fakultas Teknik, 8(1), 37-46.

Nasir, S., Amelin, H, Danni, S., 2013 Pengaruh Koagulan Polyaluminium Chloride Dan Sodium Alginate Terhadap Kualitas Air Bersih Yang Dihasilkan Pada Pengolahan Air Sungai Dan Air Rawa Dengan Filter Keramik, Jurnal Teknik Kimia, 19 (4), 7-17.

Noviani H., 2012. Analysis Using Polyaluminium Chloride Coagulant (PAC) and Chitosan In Water Purification Process in PDAM Tirta Pakuan Bogor, Skripsi, Bogor: Fakultas MIPA Universitas Pakuan.

Rukaesih, A., 2004, Kimia Lingkungan, Andi Offset, Yogyakarta.

Suwahyono, Untung, 2008, Khasiat Ajaib Si Pohon Gaib, Andi Offset, Yogyakarta.
Trestianingrum, R., Sarini Rahayu, 2013, Perbandingan Efektifitas Koagulan Tawas Dan Biji Kelor Terhadap Kadar BOD Pada Air Limbah Jasa Cuci Pakaian, Jurnal Pendidikan Biologi, FKIP, Univeristas Nusantara PGRI Kediri.

Wahyuni, N. L., 2011, Recovery Alumina $\left(\mathrm{AL}_{2} \mathrm{O}_{3}\right)$ Dari Coal Fly ash (CFH) Menjadi Pholyaluminium Chloryde (PAC), Jurnal Fluida, VII (I), 28-35.

Yudo, S., 2010, Kondisi Kualitas Air Sungai Ciliwung Di Wilayah DKI Jakarta Ditijau Dari ParameteR Organik, Amoniak, Fosfat, Detergen, Bakteri Coli, Jurnal Lingkungan,6(1), 1-9. 